\title{
Membaca Teks dalam Pandangan Poskolonial: Catatan Kritis atas Bacaan Terhadap Teks Kitab Suci
}

Ivan Sampe Buntu

Sekolah Tinggi Agama Kristen Negeri Toraja

pdt.ivansampebuntu@gmail.com

\begin{abstract}
Superior and inferior are two confronted words which are in postcolonial to build an awareness of "oppression". Oppression is not only in physical form, but more concerning is oppression in the mind. Postcolonial is a way of thinking to build an awareness of oppression. It did not merely show the residues of the Colonial mind, but at the same time gave a new postcolonial interpretation and tried to form a postcolonial identity. Postcolonial will always come into contact with two things namely text and context. Text and context are two things which always dialogue by interpreters. Thus talking about postcolonial means being unable to escape from context, text and interpreters. This paper will describe how the text deals with the context and how the interpreter treats the text. Interpreters may be wrong in treating the text (according to their interests), thus making others become subalterns. This means that the process of interpreting is also political action.
\end{abstract}

Keywords: colonial; identity; postcolonial; sacred text

Abstrak: Superior dan inferior adalah dua kata yang saling bertentangan yang ada dalam postkolonial untuk membangun kesadaran akan "penindasan". Penindasan tidak hanya dalam bentuk fisik, tetapi yang lebih memprihatinkan adalah penindasan terhadap pikiran. Postkolonial adalah cara berpikir untuk membangun kesadaran penindasan. Ini tidak hanya menunjukkan sisa-sisa pikiran kolonial, tetapi pada saat yang sama memberikan interpretasi postkolonial baru dan mencoba membentuk identitas postkolonial. Postkolonial akan selalu bersentuhan dengan dua hal yaitu teks dan konteks. Teks dan konteks adalah dua hal yang selalu di-dialogkan oleh penerjemah. Jadi berbicara tentang postkolonial berarti tidak dapat melepaskan diri dari konteks, teks, dan penerjemah. Makalah ini akan menjelaskan bagaimana teks berhubungan dengan konteks dan bagaimana penerjemah memperlakukan teks. Penerjemah mungkin salah dalam memperlakukan teks (sesuai dengan minat mereka), sehingga membuat yang lain menjadi hamba. Ini berarti bahwa proses penafsiran juga merupakan tindakan politik.

Kata-kata kunci: identitas; kolonial; poskolonial; teks Kitab Suci

$\begin{array}{llll}\text { Article History: } & \text { Received: 11-12-2018 } & \text { Revised: 20-12-2018 Accepted: 24-12-2018 }\end{array}$




\section{Pendahuluan}

Dalam refleksiknya Keshub Chunder Sen Mengungkapkan: tampaknya Kristus yang telah datang kepada kami adalah seorang Inggris, dengan budi bahasa dan adat istiadat Inggris yang dikenakan kepada-Nya, dan dengan perangai dan semangat seorang Inggris di dalam diri-Nya...Bukankah kampung halaman Kristus lebih dekat ke India daripada ke Negeri Inggris? Bukankah Yesus dan rasul-rasul-Nya dan para pengikut terdekat-Nya lebih karib dengan kebangsaan India daripada dengan orang-orang Inggris? Lalu, mengapa kami harus mengunjungi suatu negeri yang jauh seperti Inggris, untuk dapat menghimpun kebenaran-kebenaran yang dapat ditemukan jauh lebih dekat dengan tempat kami tinggal? Pergilah ke terbitnya matahari di sebelah Timur, jangan ke terbenamnya matahari di sebelah Barat, jika kamu ingin melihat Kristus di dalam kepenuhan kemuliaan-Nya. ${ }^{1}$

Pernyataan Chunder Sen diatas setidaknya ingin menggambarkan dua hal (1). Sebuah gambaran kesadaran, betapa Kristus yang telah kita kenal bukan lagi Kristus yang hidup dalam budayanya, tetapi Kristus yang telah memakai budaya barat dan dihidupi dalam budaya timur (2). Kesadaran akan kebenaran yang tidak boleh didominasi oleh Barat, tetapi bisa juga dimaknai dalam konteks Timur. Kedua gambaran ini memperlihatkan sebuah kesadaran baru, bagaimana memaknai kebenaran dalam konteks dan budaya Timur. Mengapa ini menjadi penting? Karena selama ini kita melihat bahwa kebenaran selalu terkait dengan sebuah budaya tertentu. Barat yang superior dan Timur yang inferiror. Sepertinya ukuran baik atau buruk, benar atau salah, selalu diukur dari sudut pandang budaya yang superior yakni Barat.

Situasi seperti di atas telah menimbulkan banyak pertanyaan, seperti pertanyaan Gayatri Spivak, ““'Dapatkah subaltern berbicara?”...yang dimaksud Spivak dengan 'subaltern' adalah subjek yang tertekan, para anggota 'klas-klas subaltern'-nya Antonio Gramschi... atau secara umum, mereka yang berada di 'tingkat inferior'."2 Pertanyaan ini bukan tanpa alasan, tetapi mau mengungkapkan sebuah ketidak berdayaan subaltern. Sama dengan apa yang dikatakan Derrida bahwa " ...rasional Barat yang sangat terstruktur adalah rasis dan imperialis." ${ }^{3}$ Pandangan-pandangan ini menunjukkan bahwa tidak ada ruang bagi subaltern untuk mengungkapkan nilainya sendiri. Karena ruang-ruang itu telah dibungkam oleh rasionalitas Barat.

Bukankah yang paling mengerikan, adalah ketika pikiran-pikiran kita pun dijajah. Sadar atau tidak, selama bertahun-tahun kita telah mewarisi sebuah budaya yang membuat kita menjadi inferior dihadapan Barat, sehingga kita pun sulit menemukan makna pada ketimuran kita. Menjadi lebih mengerikan, ketika agama pun turut memberi legitimasi terhadap apa yang dilakukan Barat dengan menggunakan konsep-konsep alkitab untuk melumpuhkan rasionalitas timur. Sehingga mempertanyakanpun kita seolah enggan.

Poskolonial sebagai cara berfikir yang melampaui konsep berpikir kolonial, tidak sekadar kritik atas pandangan kolonial terhadap teks, tetapi juga mencoba mengurai makna teks menjadi lebih kontekstual. Tafsir poskolonial dalam filsafat berangkat dari pendekatan filsafat Marxis, dan poststrukturalis. Postkolonial mencoba menelanjangi kajian-kajian teks yang tidak selaras dengan konteks Timur. Poskolonial adalah sikap kritis atas pikiran colonial, yang berusaha untuk tidak terjebak dalam konsep berpikir yang sama dengan colonial.

\footnotetext{
${ }^{1}$ R.S. Sugirtharajah, Wajah Yesus di Asia (Jakarta: BPK Gunung Mulia, 2007), 11.

2 Leela Gandhi, Teori Poskolonial: Upaya Meruntuhkan Hegemoni Barat (Yogyakarta: Qalam, 2007), 1

3 Ibid, 35.
} 
Selanjutnya, kalau ditinjau dari perkembangan bidang kajianya, postcolonialism muncul pertama-tama sebagai sebuah aktivitas kritis dalam studi literatur di Negara persemakmuran atau dunia ketiga. Peristiwa ini, sebagaimana dikatakan oleh Harish Trivedi, merupakan fenomena pertama dimana Negara terjajah ditempatkan di pusat wacana akademis. ${ }^{4}$

\section{Menolak Tafsir Kolonial}

Untuk menghindari transformasi ideologis ini sekaligus, katakanlah, suatu "alienasi kultural", Spivak menyarankan suatu siasat yaitu agar pembaca menjadi "dirinya sendiri" dengan cara menolak gagasan hegemonik itu melalui apa yang dikatakan Spivak sebagai "menunda persetujuan" (a willing suspension of disbelief).$^{5}$

Spivak tidak hanya menyatakan bentuk penolakan terhadap hegemoni Barat, tetapi sekaligus menginginkan keotentikan manusia Timur, yang disebutnya menjadi "diri sendiri". Menjadi diri sendiri, adalah sebuah proses kesadaran akan diri. Atau lebih tepatnya proses pengenalan aku sebagai subjek. Nampaknya sulit untuk memulai penolakan atas hegemoni tanpa kesadaran subjek. Kesadaran akan ketertindasan menjadi penting untuk mulai melakukan kritik terhadap teks.

Salah satu yang dilihat oleh Spivak sebagai bentuk hegemoni Barat adalah cara pandang terhadap sastra. "Menurut Spivak, kita harus menolak pembedaan sastra Barat sebagai "sentral" dan sastra dunia ketiga sebagai "marginal". Sebaliknya kita harus memperhatikan segala kemungkinan heterogenitas dalam kedua kategori tersebut."6 Memberi ruang terhadap heterogenitas menjadi sesuatu yang penting. Mengapa? Karena disana kita akan melihat keunikan dari sastra yang ada, yang masingmasing mempunyai makna. Jika Spivak menolak dominasi sastra Barat, maka ini menjadi sangat logis. Menjadikan sastra Barat sebagai sentral, sama dengan membuang keunikan pada yang lain. Sehingga secara perlahan kita sedang mengafirmasi kebenaran-kebenaran tertentu dan membuang yang lain tanpa kompromi. Senada dengan pernyataan Richard Rorty seperti dikutip Piliang Bahwa:

...cukup aneh memikirkan kenyataan bagaimana kita (Barat) menganggap dan memperlakukan orang-orang dari masyarakat dan kebudayaan lain sebagai terbelakang, inferior, statis, sinting, tolol, hina, penuh dosa orang-orang yang tidak pantas dianggap sebagai mitra perbincangan dan wacana; orang-orang yang kita tidak dapat belajar apapun dari mereka. ${ }^{7}$

Konsekuensi dari sikap seperti diatas telah melahirkan sikap superior dan inferior. Sikap tersebut dihidupi dalam keseharian masyarakat, misalnya pada suku tertentu yang dikristenkan oleh para misionaris, ketika mereka menjadi kristen, maka nama merekapun diganti dengan nama yang baru.

Produk budaya yang dilahirkan dari refleksi keseharian masyarakat setempat banyak yang dihilangkan, karena dianggap bertentangan dengan kebenaran injil. Di mana injil yang dimaksudkan sendiri adalah produk yang telah dibungkus dengan budaya tertentu (budaya Barat). Ini merupakan gambaran, bagaimana hidup keseharian

\footnotetext{
${ }^{4}$ Wijanarko, Robertus, "Poskoloialisme dan studi teologi: sebuah pengantar.” Jurnal, Studia, philosophica et theological, Vol. 8 No. 2 Oktober 2008, STFT Widya Sasana Malang. Hlm. 128

${ }^{5}$ M.H. Nurul Huda. Membongkar kekerasan epistimis dalam Hermeneutika Pascakolonial: soal identitas. Editor Mudji Sutrisno dan Hendar Putranto (Yogyakarta: Kanisius, 2004), 118.

${ }^{6}$ Ibid.

7 Yasraf Amir Piliang, Dunia Yang Dilipat: Tamasya Melampaui Batas-Batas Kebudayaan (Bandung: Matahari, 2010), 398.
} 
masyarakatpun telah dipengaruhi oleh cara berpikir barat. Sehingga yang berbau Barat selalu identik dengan kebenaran dan kebaikan.

Tafsir kolonial terhadap realitas Timur tidak hanya hidup dalam pikiran, tetapi juga dihidupkan dalam doktrin agama. Lebih memprihatinkan bahwa proses kolonisasi yang dulu hanya dilihat sebagai bentuk penghisapan kekayaan alam dan penindasan fisik, kini proses kolonisasi tersebut telah mewujud dalam bentuk barunya seperti dikatakan oleh Smith bahwa:

Meski secara formal mereka sudah pergi, sesungguhnya institusi dan warisan kolonial mereka masih tertinggal. Dekolonisasi yang dulu dipandang sebagai proses formal peralihan instrument pemerintah, kini dipahami sebagai proses jangka panjang yang melibatkan kekuasaan, kultural, linguistis, dan psikologis Kolonial. ${ }^{8}$

Kolonialisme dalam bentuk yang lain telah hidup dalam keseharian manusia, celakanya para politisi pun turut memberi legitimasi terhadap penghisapan tersebut. Pada kondisi yang lebih riil, dapt dilihat bagaimana masyarakat mengidentikan diri mereka dengan gaya hidup Barat, dari makanan sampai fashion. Budaya pribumi tinggal menjadi obyek yang tidak lagi memberi nilai apapun, tetapi hanya dinikmati sebagai sebuah tontonan.

Kebergantungan kepada Barat menjadi tidak terelakkan dalam hal ini. Di mana Timur yang identik dengan inferior selalu membutuhkan Barat yang superior. Layaknya seperti seorang anak yang selalu membutuhkan ayah atau ibu. Kemandirian harusnya menjadi keniscayaan dalam melawan tafsir dominan Barat.

Colonial and imperial rule was legitimized by anthropological theories which increasingly portrayed the peoples of the colonized world as inferior, childlike, or feminine, incapable of looking after themselves (despite having done so perfectly well for millennia) and requiring the paternal rule of the was for their own best interests (today they are deemed to require development). ${ }^{9}$

Kebergantungan ini, tentu saja adalah kebergantungan yang tidak ada begitu saja, tetapi diciptakan dalam pikiran masyarakat Timur. Timur selalu digambarkan seperti anak kecil yang selalu membutuhkan bapaknya yakni Barat (baca konsep oposisi biner).

Tafsir-tafsir seperti ini tentu bukan tanpa alasan dihidupkan di Timur. Tetapi dapat dicurigai sebagai bentuk penindasan baru dan penguasaan akan kekayaan alam. Tafsir terhadap konsep seperti ini sangat jelas terlihat dalam konsep "oposisi biner." 10 Konsep yang sesungguhnya sangat problematis. Kategori yang satu menjadi lebih superior dari kategori yang lain. Ini merupakan cara pandang Barat melihat Timur dengan konsep oposisi biner yang telah melahirkan tafsir Kolonial.

\footnotetext{
${ }^{8}$ Linda Tuhiwai Smith. Dekolonisasi Metodologi (Yogyakarta: Insist press, 2005), 147-148.

${ }_{9}^{9}$ Robert J.C. Young. Postcolonialism: A Very Short Introduction (New York: Oxford University Press, 2003), 2.

10 Gading Sianipar. Mendefenisikan Pascakolonialisme: pengantar menuju wacana pemikiran pascakolonialisme, dalam Hermeneutika Pascakolonial: soal identitas. Editor Mudji Sutrisno dan Hendar Putranto (Yogyakarta: Kanisius 2004), 20. Oposisi biner merupakan bentuk paling ekstrim dari perbedaan yang mungkin terjadi. Misal: perempuan $><$ laki-laki, lahir $><$ mati, hitam $><$ putih, menang $><$ kalah, beradab $><$ primitif, rasional $><$ irasional, dan sebagainya. ...persoalan yang muncul dalam sistem biner ini mengabaikan adanya ambiguitas atau ruang antara, antara kategori-kategori yang beroposisi. Karena banyak kategori yang hadir di antara kategori kawan $><$ lawan, anak-anak $><$ dewasa, laki-laki $><$ perempuan, yang dalam oposisi biner tidak dapat diaokomodasi. Bila ditarik lebih jauh lagi, logika imperialisme merupakan perkembangan dari cara pandang Eropa yang memandang dunia dalam relasi oposisi biner. Pemisahan sederhana antara pinggir/pusat; penjajah/terjajah; berbudaya/primitif, menghadirkan hierarki kekuasaan di mana imperialism dibangun dan dipertahankan.
} 
Konsep ini tidak bisa dilihat secara sederhana. Karena tidak dapat dinafikan bahwa konsep oposisi biner pun telah merasuk masuk dalam cara pandang Barat melihat teks Alkitab. Misalnya, ucapan bahagia dalam khotbah dibukit, berbahagialah yg miskin, berdukacita, lapar dan haus akan kebenaran, dianiaya dst. Membawa dalam konsep oposisi biner, maka kemiskinan beroposisi dengan kaya, berdukacita dengan yang gembira, lapar dan haus dengan yang kenyang, dianiaya dengan yang bebas dll. Jika orang miskin adalah penghuni surga, maka orang kaya identic dengan penghuni neraka, dst. Tidak ada pilihan lain dalam hal ini, itu sebabnya mereka yang tertindas, dianiaya menerima dalam iman ketertindasannya sebagai anugerah. Mengapa? Karena oposisi dari itu tidak mengandung kepastian. Tidak mungkin dua duanya menjadi benar dan dua duanya mengandung kepastian. Jika yang satu mengandung kepastian, maka yang satu pasti tidak mempunyai kepastian.

Sugirtharajah mengatakan bahwa: "Cara bertelologi pada masa kini adalah menjumpai agama-agama sebagaimana agama itu memandang dirinya sendiri ketimbang menilai agama-agama itu dengan kaidah-kaidah yang sudah ditentukan sebelumnya." 11 Teologi tidak lagi dipahami dalam konsep dan kaidah-kaidah tertentu, tetapi berteologi adalah memahami konteks. Konteks dalam hal ini menjadi sesuatu yang perlu dimaknai secara baru, di mana Allahpun berkarya didalamnya melalui berbagai tradisi yang ada. Teks harus mulai ditafsir dengan cara baru, sehingga injil yang disampaikan itu menjadi injil yang benar-benar hidup dalam konteks. Yesus yang ada benar-benar menjadi wajah yang menampilkan sikap belarasa terhadap mereka yang ditindas, bukan lagi Yesus yang ditampilkan memberi legitimasi atas kekuasaan.

\section{Pencarian Identitas Poskolonial}

Identitas menjadi hal penting untuk mengenal diri kita atau komunitas kita. Mengapa ini penting? Karena dunia sedang membentuk kita berdasarkan keinginan dan kepentingannya. Artinya identitas manusia hari ini, adalah identitas yang sebagian terbentuk oleh sebuah konstruksi dari luar dirinya. Seperti diungkapkan oleh Hendar Putranto atas tafsirannya pada buku The power of identity, Manuel Castells "Dunia dan hidup kita sedang dibentuk oleh trend-trend yang saling bergesekan, yaitu globalisasi dan identitas." 12 Salah satu yang sangat mempengaruhi hidup manusia hari ini adalah Globalisasi, yang telah menawarkan berbagai kemudahan-kemudahan. Bisa dikatakan bahwa roh kolonialis dan imperialis pun ada bersama dengan globalisasi.

Globalisasi dengan doktrin-doktrinnya, telah berhasil menggunakan media sebagai alat propaganda. Propaganda tersebut telah melahirkan manusia dengan identitas baru, yang mengikuti apa kata pemilik modal. Ini menjadi sesuatu yang sungguh mengerikan. Di mana manusia tidak lagi mengenal dirinya, karena dia telah dikonstruksi oleh sebuah kekuatan besar diluar dirinya. Setidaknya ada tiga kekuatan yang dapat mengkonstruksi manusia berdasarkan doktrin dan ideology yang diusungnya. Tiga kekuatan itu antara lain: Globalisasi, agama dan budaya. Saat ini globalisasi adalah kekuatan paling menakutkan dalam konstruksi makna. Mengapa? Karena globalisasi telah mempunyai kekuatan propaganda yang luar biasa lewat media. Sedangkan agama dan budaya, juga tidak dapat dinafikan. Karena tidak bisa dipungkiri bahwa kekuatan agama sejak awal telah menciptakan konstruksi makna melalui kitab sucinya.

11 R.S. Sugirtharaja. Suatu Pengantar Penjelas dalam Wajah Yesus, Sugirtharaja, 15.

12 Hendar Putranto. "Wacana Pascakolonial Dalam Masyarakat Jaringan" dalam Hermeneutika Pascakolonial, Editor Mudji Sutrisno dan Hendar Putranto (Yogyakarta: Kanisius, 2004), 86. 
Agama dapat dikatakan mempunyai kekuatan luar biasa terhadap pengikutnya. Contoh kongkret, seseorang bisa melakukan tindakan bunuh diri atau membunuh sesamanya tanpa rasa bersalah atas nama doktrin agama. Dengan demikian bahwa konstruksi makna menjadi hal yang benar-benar sangat penting. Karena manusia dapat dibentuk berdasarkan konstruksi makna dari luar dirinya, sehingga identitasnya menjadi kabur. Pertanyaan menarik adalah, apakah konstruksi makna juga terjadi dalam sistem Kolonial? Secara sederhana kita dapat mengatakan bahwa konstruksi makna itu terjadi. Ini terlihat dari cara pikir dan bertindak orang-orang yang telah dijajah menjadi orang yang inferior dan seperti menerima situasi itu sebagai nasib yang harus dihadapi. Pada sisi lain, banyak yang kemudian meninggalkan budayanya dan mulai beralih pada budaya tertentu yang dianggapnya lebih baik. Sehingga dapat dikatakan bahwa orangorang yang terjajah sering kali kehilangan identitasnya.

Pencarian identitas dan perlawanan terhadap kapitalis seperti diungkapkan Castells terlihat dalam kelompok fundamentalisme sebagai lawan dari kapitalisme, sosialisme dan nasionalisme. Kelompok ini membentuk identitas mereka sebagai lawan dari kegagalan Negara dalam menata masyarakatnya. Korupsi, kebergantungan terhadap asing membuat Negara-bangsa mengalami krisis legitimasi, yang membuat kelompok tertentu membentuk identitasnya sendiri. "Konstruksi identitas Islam kontemporer dengan demikian merupakan reaksi melawan modernisasi yang tidak tercapai (entah itu dalam bentuk kapitalis maupun sosialis)."13 Konstruksi identitas ini merupakan konstruksi yang dilakukan pada kelompok dan bukan pada individuindividu.

Castells merumuskan "fundamentalisme" sebagai "konstruksi identitas kolektif di bawah panji identifikasi perilaku individu dan lembaga-lembaga kemasyarakatan dengan norma-norma yang dialih turunkan dari hukum Ilahi, dan ditafsirkan oleh otoritas tertentu yang menjadi pengantara antara Allah dan kemanusiaan. ${ }^{14}$

Subjek sebagai penafsir selalu dipengaruhi oleh pengalaman keseharian dan konteks di mana dia hidup. Sehingga penafsir teks dapat menafsirkan teks berdasarkan pengaruh dari konstruksi makna yang telah menguasainya. Artinya teks dapat ditafsirkan oleh subjek berdasarkan kepentingan tertentu. Patut untuk mencurigai setiap penafsir yang berangkat dari konteks tertentu dan menafsirkan sebuah teks. Tidak ada penafsir yang bebas nilai, itu sebabnya penafsir akan menafsir berdasarkan kesadaran reflektifnya. Teks yang sama bisa berbeda di tangan orang yang berbeda.

Berbahagialah hai kamu yang miskin, sebab kamulah yang empunya kerajaan Allah" (Lukas 6:20), marilah kita bertanya, siapa orang yang sedang mengatakan ini, dan kepada siapa? Apakah seorang kaya yang mengatakan ini kepada seorang manusia yang sangat kelaparan? Orang kaya kepada orang miskin? Orang yang dapat membaca kepada orang yang buta aksara? Orang yang gisinya terpenuhi kepada orang yang kelaparan? Jika seorang, dengan mengutip nats Alkitab, mengatakan "manusia tidak hanya hidup dari roti saja, tetapi dari setiap firman yang keluar dari mulut Tuhan", maka mari kita bertanya lagi, siapa mengatakan ini dan kepada siapa? ${ }^{15}$

\footnotetext{
13 Ibid, 88.

14 Ibid, 88-89.

15 Kosuke Koyama, “Kristus Yang Disalibkan” dalam Sugirtharajah Wajah Yesus, 238-239.
} 
Seorang penafsir dalam hal ini mempunyai pengaruh ke mana teks ini akan didaratkan. Seorang penindas dapat saja menggunakan teks tersebut sebagai alat untuk melegitimasi kekuasaannya. Atau menggunakan teks tersebut sebagai alat untuk memberi kedamaian pada yang ditindas. Identitas itu harus ditemukan oleh manusia dari refleksinya lam refleksi pribadinya dalam konteks. Pencarian identitas poskolonial hanya dapat terjadi jika manusia benar-benar merefleksikan dirinya dalam konteks. Karena tidak ada seorangpun yang bebas nilai, tidak ada penafsir yang bisa membebaskan dirinya dari nilai-nilai yang telah dihidupinya.

\section{Tafsir Teks Sebagai Pembenaran akan Sesuatu}

Mencari legitimasi kebenaran atas sebuah tindakan, nampaknya akan mudah didapatkan dalam Alkitab Mulai dari persoalan kuasa, dagang sampai pada tindakan tidak bermoral, nampaknya manusia dapat mencari pembenarannya dalam Alkitab. Sugirtharajah menyebut beberapa contoh bagaimana Alkitab digunakan untuk membenarkan tindakan-tindakan yang sesunggunya bertentangan dengan persoalan kemanusiaan. Beberapa contoh yang disebut: Misalnya, tahanan rumah seperti yang dikenakan oleh rezim Afrika dalam zaman Apartheid di Afrika Selatan, didukung oleh pernyataan Alkitab. Brigadir Neels Du Plooy menjelaskan bahwa banyak undang-undang keamanan selama periode menindas didasarkan pada ajaran Alkitab.

Misalnya, tahanan rumah bisa dibenarkan oleh 1 Raja-raja 2:36: Kemudian raja menyuruh memanggil Simei, dan berkata kepadanya: "Dirikanlah bagimu sebuah rumah di Yerusalem, diamlah di sana, dan janganlah keluar dari sana ke mana-mana pun. Dalam kasus lain, pemilik kembang gula Logia Foods mengklaim bahwa perusahaannya hanya memasarkan makanan yang ditentukan oleh Alkitab (makanan halal). Dia mengaku bahwa produknya, Bible Bar, dibuat sesuai dengan bimbingan nutrisi yang ditentukan dalam Kitab Suci dengan mengutip kitab Ulangan 8:8: "Suatu negeri dengan gandum dan jelainya, dengan pohon anggur, pohon ara dan pohon delimanya; suatu negeri dengan pohon zaitun dan madunya." Bahkan, kloning embrio manusia memiliki sumber alkitabiah langsung. Severino Antinori, yang berada di tengah-tengah kontroversi atas kloning manusia dan reproduksi manusia, mengatakan bahwa itu adalah 'kekaguman pada kisah Perjanjian Lama tentang usia Sara istri Abraham yang menyebabkan kemasyhuran di seluruh dunia dan kemasyhurannya. ${ }^{16}$

Alkitab dalam hal ini telah ditafsirkan berdasarkan keinginan dan kepentingan. Membenarkan tindakan yang represif dapat dilakukan dengan legitimasi Alkitab. Ini menjadi menarik, karena bible telah ditempatkan sebagai tameng untuk membenarkan tindakan yang tidak manusiawi. Agama dengan demikian hanya menjadi pemberi legitimasi atas kepentingan penafsir teks. Penafsir telah menggunakan subjektivitasnya untuk memberi makna baru terhadap apa yang ada dalam teks. Teks seperti menjadi hidup ditangan penafsir, tetapi dia dihidupkan untuk kepentingan sang penafsir. Seperti diungkapkan oleh Itumeleng J. Mosala,

That the Bible is a thoroughly political document is eloquently attested to by its rolein the Apartheid system in South Africa. No other political or ideological system in the modern world that I know of derives itself so directly from the Bible as the ideology of Apartheid. The superiority of white people over black people, for example, is premised

16 R.S. Sugirtharajah, Postcolonial Reconfigurations-An Alternative Way of Reading the Bible and Doing Theology (USA: Chalice Press, 2003), 75 
on the divine privileging of the Israelites over the Canaanites in the conquest texts of the Old Testament. ${ }^{17}$

Gaya berpikir seperti ini adalah gambaran cara berpikir Kolonial. Di mana penafsir mengurai teks berdasarkan keinginan dan kehendaknya. Cara tafsir seperti ini, tentu tidak mungkin untuk dibenarkan, karena mereka telah melupakan konteks dari teks, dan menarik teks-teks tertentu berdasarkan keinginan.

Seperti diungkapkan Schleiermacher dalam memahami bahasa, yang mana "bahasa sebagai ekspresi diri estetis yang mengekspresikan subjektivitas seseorang."18 Dapat dikatakan bahwa ini merupakan sebuah ekspresi diri dari penafsir untuk mengungkapkan identitasnya. Dalam hal ini subjek sebagai penafsir adalah sangat penting. Karena itulah menjadi logis pertanyaan yang menanyakan, siapa yang mengatakan tentang apa. Karena menafsir sama dengan menunjukkan identitas manusianya. Jika seorang penafsir adalah seorang yang berkuasa, maka dia pasti menafsirkan teks berdasarkan kepentingan kekuasaannya. Tetapi sebaliknya jika penafsir adalah seorang yang tertindas, maka dia akan menafsirkan teks berdasarkan pengalaman ketertindasannya.

Posisi penafsir sebagai subjek menjadi sangat penting. Karena dia dapat melegitimasi teks berdasarkan pada keinginannya sendiri. Seperti telah dijelaskan sebelumnya bahwa seorang kaya bisa saja mengatakan kepada seorang miskin "Berbahagialah hai kamu yang miskin, sebab kamulah yang empunya kerajaan Allah" (Lukas 6:20). Sementara si kaya sedang menikmati santap siangnya di restoran mewah dan tidur dengan kasur yang mentul-mentul, sedangkan si miskin hidup dibawah jembatan dengan beralaskan koran sebagi tempat tidurnya. Tidakkah ini menjadi tafsir yang sangat menyedihkan. Dengan demikian si kaya akan menikmati kekayaanya tanpa perlu membaginya kepada si miskin, karena si kaya telah memberinya candu untuk dinikmati. Menjadi tepatlah kritikan Marx terhadap agama bahwa "agama hanyalah candu".

\section{Metode Penelitian}

Artikel ini berisikan sebuah kajian dengan penelitian kualitatif literatur pada pola pembacaan kitab Suci di masa poskolonial. Metode yang digunakan adalah deskriptif, yaitu memberikan gambaran yang jelas tentang pola pembacaan pada masa poskolonial yang berimbas pada pola pembacaan kitab suci di masa kini. Beberpa teori para ahli digunakan untuk mendukung dan memberikan pengertian tentang pola pembacaan teks kitab suci di masa poskolonial, serta implikasinya pada masa sekarang ini.

\section{Hasil dan Pembahasan \\ Menafsir Teks Membebaskan Pikiran Kolonial}

Menarik bahwa mereka yang melakukan refleksi tentang Yesus adalah orang-orang India non Kristen dan bukan orang Kristen Asia. Refleksi mereka telah melahirkan gambaran beragam misalnya, seperti diungkapkan Raja Ram Mohun Roy bahwa Yesus adalah pemandu Agung Utama manusia untuk menemukan kebahagiaan. Yesus sebagai Yogi sejati dan manusia Ilahi, seperti ungkapan Keshub Chunder Sen. Yesus sebagai sang Anak Manusia, yang mencari yang terakhir yang terkecil dan yang hilang, oleh Rabindranath Tagore. Yesus sebagai Satyagrahi Agung Utama (pengasih dan pencari

\footnotetext{
${ }^{17}$ Itumeleng J. Mosala, “The Implications of the Text of Esther for African Women's Struggle for Liberation in South Africa" dalam The Postcolonial Biblical Reader. Editor R.S. Sugirtaharajah (USA: Blackwell Publishing, 2006), 135.

${ }^{18}$ Inyiak Ridwan Muzir. Hermeneutika Filosofis Hans Georg Gadamer (Yogyakarta: Ar Ruzz Media, 2008), 172.
} 
kebenaran) seperti disampaikan Mahatma Gandhi. Kristus mistik diungkapkan oleh Radhakrishan. ${ }^{19}$ Semua gambaran Yesus ini merupakan refleksi dari sebuah konteks yang secara serius melihat Yesus dalam dunia mereka sendiri dan bukan dalam budaya Barat.

Menafsirkan wajah Yesus dalam konteks Asia menjadi sesuatu yang menarik. Seorang yang bernama Yesus yang berkebangsaan Asia, ditafsirkan ulang dalam konteks Asia, karena telah kehilangan rohnya di Asia. Wajah Yesus yang kita kenal adalah ciptaan budaya tertentu yang terlalu jauh bagi orang Asia. Yesus yang ditampilkan, ditampilkan dalam wajah penindas yang memberi legitimasi bagi penguasa. Wajah Yesus yang ditampilkan di Asia adalah, sosok yang menerima kemiskinan sebagai bagian dari kehidupan yang harus diterima apa adanya. Bentuk perlawanan dan sikap kritis terhadap penguasa sering dianggap bertentangan dengan injil. Sugirtharajah menyebut bahwa:

Orang-orang Asia telah mewarisi gambaran-gambaran mengenai Yesus yang secara luas dapat digolongkan di bawah dua bagian pokok: Kristus pengakuan dan Kristus ajaran/ideologis. Yang pertama telah terbentuk melalui adu-adu pendapat di dalam konsili-konsili agung oikumenis, khususnya konsili Chalcedon. Yang kedua dipengaruhi oleh kebutuhan-kebutuhan ideologis untuk memperluas kekristenan pada zaman pekabaran injil pada permulaan zaman modern. Tidak satupun dari rancang-rancang bangun mengenai Yesus ini menaruh perhatian sungguh-sungguh pada usaha untuk menemukan kembali Yesus yang sebenarnya. ...tanpa harus menyangkali lingkungan Yahudi-Nya. ${ }^{20}$

Dampak dari warisan tentang wajah Yesus ini, telah dihidupi dalam konteks Asia. Hal ini berdampak pada cara beriman orang Asia. Di mana di sana ada ada warisan pemikiran yang melihat yang lain sebagai subaltern. Sehingga memaknai Kristus sering terlihat pada bagaimana mengkristenkan yang lain bukan bagaimana "mengkristuskan".

Roh dari konsep seperti ini dihidupi oleh para misionaris awal, yang melihat yang lain sebagai objek, dan mereka adalah subjek yang dapat menentukan identitas yang lain. Inilah yang menjadi pertanyaan Spivak dapatkah subaltern berbicara? Menemukan Yesus yang sebenarnya dalam konteks Asia, mungkin sama dengan menemukan kembali identitas kita. Mengapa saya katakan menemukan kembali identitas? Sebab menemukan wajah Yesus di Asia sama halnya dengan memulai sebuah cara berpikir baru dalam nilainilai Timur.

Masalah yang sering kali muncul adalah, ketika kontekstualisasi (inkulturasi) coba dilakukan dalam konsep Timur, maka seringkali dicurigai sebagai sinkretisme. Seperti diungkapkan oleh Gerit Singgih bahwa: "Hal ini baru menjadi persoalan apabila "kakak seiman" itu mengklaim bahwa hanya kontekstualisasinyalah yang safe [kontekstualisasi Barat], sedangkan bila hal serupa dilakukan oleh orang Timur, tindakan itu akan menjurus pada sinkretisme." 21 Kecurigaan seperti ini mengindikasikan bahwa konsep superior-inferior masih terpelihara dengan baik dalam pikiran Barat. Dampak dari sikap superior itu akhirnya memandang Timur dalam cara berpikir Barat, yang kemudian berdampak pada kebergantungan. Menemukan kembali injil dan memaknainya dalam

19 Sugirtharajah. Wajah Yesus, 13-14.

20 Ibid, 415.

${ }^{21}$ E.G.Singgih. Dari Israel Ke Asia- Masalah Hubungan Antara Kontekstualisasi Teologi Dengan Interpretasi Alkitabiah (Jakarta: BPK Gunung Mulia, 2012), 14-15. 
konsep Timur menjadi sesuatu yang sangat penting, agar Timur benar-benar menghidupi injil dalam cara berimannya sendiri.

Memaknai injil dalam konsep Timur menjadi keniscayaan, agar mereka yang percaya pada Kristus tidak menjadi penindas baru bagi sesamanya. Seperti yang terjadi dalam sejarah misionaris di Toraja oleh orang-orang Ambon dan manado yang menganggab budaya mereka lebih tinggi dari orang Toraja karena telah menjadi Kristen. Di negeri asal mereka (Ambon dan Menado). Adat mereka telah dibaptiskan sebagai "adat Kristen". Oleh karena itu mereka menganggap diri sebagai penganut kebudayaan yang lebih tinggi sedangkan budaya setempat sebagai budaya yang rendah yang masih percaya kepada kepercayaan yang sia-sia. ... pada pihak lain ada beberapa orang Menado dan Ambon sebagai pegawai pemerintah yang hidupnya agak elite...itu berpengaruh pula kepada orang Kristen Toraja yang masuk ke pergaulan elite tersebut. ${ }^{22}$

Warisan kolonial nampak sangat jelas dalam cara berpikir mereka yang telah menjadi Kristen. Menganggap budaya mereka lebih tinggi dari yang lain. Sehingga yang lain dianggap hanya sebagai objek yang bisa diperlakukan sekehendak hati mereka. Mereka yang dianggap "kafir" disebut sebagai orang-orang yang tidak berbudaya. Sratifikasi sosial diciptakan secara perlahan tetapi pasti dalam alam berpikir kekristenan. Konsep ini jelas telah melahirkan konsep oposisi biner, antara tuan versus hamba, atau kekristenan versus agama suku. Penulis tidak akan mengurai ini lebih jauh karena kita akan terjebak pada teologi agama-agama. Tetapi penulis memperlihatkan ini untuk secara objektif melihat cara berpikir Barat yang hadir dengan agama Kristen yang telah dibungkus dalam budaya mereka sendiri.

Menafsirkan ulang teks berdasarkan konteks menjadi sesuatu yang sangat penting, tanpa harus melupakan konteks dari teks itu sendiri. Pertanyaan yang rumit dan mendasar dari penafsir adalah, apakah kita harus menafsirkan teks alkitab berdasarkan keinginan konteks? Sebab jika hal ini terjadi, maka ini pun menjadi problematis. Karena disatu sisi teks bisa menjadi sangat sosialis, dan di sisi lain akan menjadi sangat kapitalis berdasarkan siapa penafsirnya. Tentu kita tidak mengharapkan teks yang seperti ini, karena dengan demikian teks telah kita bawa dalam jurang relativisme. Sehingga kebenaran teks selalu terkait dengan siapa yang menafsirkan. Sugirtharajah pun mengakui kerumitan dan tantangan baru dalam menafsirkan teks berdasarkan konteks Asia. Tetapi satu yang pasti bahwa kita tidak menafsirkan teks untuk menjadi superior dari yang lain, karena dengan demikian kita hanya menganti posisi penindas.

Salah satu teks yang mungkin bisa kita lihat sebagai sebuah penafsiran teks pascakolonial, seperti yang terjadi dalam penafsiran teks oleh perempuan Afrika dalam Kitab Ester. Di mana dalam pasal 1 Ratu Wasti menolak untuk menghadiri perjamuan (perayaan) yang diadakan raja. Ini tidak hanya bermakna penolakan biasa, tetapi dapat dimaknai dalam dua hal: Pertama, sebagai bentuk perlawanan terhadap budaya patriarki yang mendominasi. Kedua, adalah sebagai bentuk penolakan terhadap sebuah gaya hidup yang hanya memboroskan uang tetapi tidak memberi dampak peningkatan ekonomi bagi rakyat. ${ }^{23}$ Artinya penolakan Ratu Wasti adalah pemberontakan antipatriarki. Dan, pada sisi lain dia dapat ditafsirkan sebagai bentuk perlawanan terhadap kaum feodal dan kapitalis.

Pada sisi yang lain, seorang bernama Ester disusupkan masuk dalam istana oleh ayah angkatnya yakni Mordekhai. Rencana ini berhasil dengan baik melalui sebuah

\footnotetext{
${ }^{22}$ Sarira, Y.A. Rambu Solo dan Persepsi Orang Kristen Tentang Rambu Solo (Rantepao: Pusbang Gereja Toraja 1996), 177.

${ }^{23}$ Itumeleng, The Implications of the Text, 138
} 
sayembara ratu kecantikan. Di mana Ester berhasil menarik hati Raja Ahasyweros dan mendapatkan kepercayaan raja. Situasi ini tidak disia-siakan oleh Ester, dengan meminta apa saja kepada Raja. Permintaan politik pun dilakukan oleh Ester, dengan membebaskan bangsanya dari tekanan politik yang dilakukan oleh Haman seorang pembesar. Meskipun kita melihat bahwa tindakan Ester pun adalah berlebihan, karena justru dia mengganti posisi para penindas dengan membunuh setiap orang yang mengancam bangsanya. Artinya Ester dan bangsanya sebagai subaltern, ketika dia mempunyai pengaruh dia membalikkan situasi dan menjadikan yang lain sebagai subaltern.

Posisi Ester yang menjadikan yang lain sebagai subaltern, tidak mungkin kita kategorikan sebagai bentuk tafsir poskolonial. Tetapi, posisi Ratu Wasti menjadi penting untuk dicermati, Wasti telah memperlihatkan sebuah penolakan terhadap dominasi kuasa kaum feodal yang sangat patriarki. Wasti telah menunjukkan identitasnya bukan sebagai subaltern, tetapi sebagai subjek yang bebas tanpa harus menjadikan yang lain sebagai subaltern. Teks Kitab Ester ini, setidaknya menjadi gambaran bagaimana kita sebagai penafsir bisa mengurai teks dan mendialogkannya dengan konteks. Paul Ricoeur menyebutnya sebagai lingkaran hermeneutik.

\section{Kesimpulan}

Siapakah yang mempunyai kuasa dan diberi kewenangan untuk menafsir teks? Ini menjadi sebuah pertanyaan reflektif yang tidak mudah untuk dijawab. Dalam protestan sendiri setiap orang mempunyai hak untuk memberi tafsiran terhadap teks berdasarkan kaidah penafsiran yang ada dengan tidak melupakan konteks dan bahasa asli dari teks. Problem yang terjadi adalah teks seringkali menjadi alat legitimasi atas kepentingan, seperti yang telah banyak terjadi dalam sejarah. Dengan demikian apakah otoritas penafsiran teks harus dikembalikan kepada kaum klerus? Sejarah pun telah membuktikan bahwa telah banyak korban yang diakibatkan oleh penafsiran absolut dari kaum klerus/imam. Abad pertengahan telah menjadikan para imam terlalu besar otoritasnya. Lalu, pada siapa teks akan mempunyai otoritasnya sendiri? Secara an sich teks alkitab sesungguhnya telah menyatakan otoritasnya sendiri. Karena itu "intensionalitas" pada teks menjadi sesuatu yang sangat penting untuk menemukan makna dari teks itu sendiri. Sehingga kitapun tidak lagi menggunakan tafsir atas dasar kepentingan kita untuk mengurai teks.

Teks dapat berbicara dan punya otoritasnya sendiri, Martin Luther secara tegas memberi ruang yang sangat besar kepada teks (sola scriptura), ketika para penafsir (para imam) terlalu besar kuasanya atas teks. Apakah dengan demikian teks tidak mungkin untuk ditafsirkan? Pembaca adalah penafsir teks. Ketika teks itu telah keluar, maka teks tersebut tidak lagi menjadi milik sang pemilik teks, tetapi dia menjadi milik pembaca. Sehingga setiap pembaca sesungguhnya adalah penafsir. Setiap pembaca dengan demikian akan membaca teks berdasarkan pengalaman religious dan kepentingannya. Subjek adalah penafsir, karena itu setiap subjek unik dalam menafsirkan teks. Kebenaran tidak mungkin lagi ditarik dalam konsep universal, tetapi hanya mungkin dipahami dalam perjumpaan dan pengalaman keseharian. Dengan demikian pos-kolonial akan menafsir teks berdasarkan pengalaman religius dan menarik kebenaran berdasarkan keunikan pada dirinya. 


\section{Referensi}

Gandhi, Leela. Teori Poskolonial: Upaya Meruntuhkan Hegemoni Barat. Yogyakarta: Qalam, 2007.

Hendar Putranto. Wacana Pascakolonial Dalam Masyarakat Jaringan dalam Mudji Sutrisno dan Hendar Putranto (ed), Hermeneutika Pascakolonial (Yogyakarta: Kanisius, 2004.

Huda, M.H. Nurul. "Membongkar kekerasan epistimis” dalam Hermeneutika Pascakolonial: Soal Identitas. Editor Mudji Sutrisno dan Hendar Putranto. Yogyakarta: Kanisius, 2004.

Kosuke Koyama, "Kristus Yang Disalibkan” dalam Sugirtharajah Wajah Yesus di Asia. Jakarta: BPK Gunung Mulia, 2007.

Mosala, Itumeleng J. “The Implications of the Text of Esther for African Women's Struggle for Liberation in South Africa" dalam The Postcolonial Biblical Reader. Editor R. S. Sugirtaharajah. USA: Blackwell Publishing, 2006.

Muzir, Inyiak Ridwan. Hermeneutika Filosofis Hans Georg Gadamer, Yogyakarta: Ar Ruzz Media, 2008.

Piliang, Yasraf Amir. Dunia Yang Dilipat: Tamasya Melampaui Batas-Batas Kebudayaan. Bandung: Matahari, 2010.

Sarira, Y.A. Rambu Solo dan Persepsi Orang Kristen Tentang Rambu Solo. Rantepao: Pusbang Gereja Toraja 1996.

Sianipar, Gading. "Mendefenisikan Pascakolonialisme: pengantar menuju wacana pemikiran pascakolonialisme," dalam Hermeneutika Pascakolonial: soal identitas. Editor Mudji Sutrisno dan Hendar Putranto. Yogyakarta: Kanisius 2004.

Singgih, E.G. Dari Israel Ke Asia- Masalah Hubungan Antara Kontekstualisasi Teologi Dengan Interpretasi Alkitabiah. Jakarta: BPK Gunung Mulia, 2012.

Smith, Linda Tuhiwai. Dekolonisasi Metodologi. Yogyakarta: Insist Press, 2005.

Sugirtharajah, R.S. Postcolonial Reconfigurations-An Alternative Way of Reading the Bible and Doing Theology, USA: Chalice Press, 2003.

Sugirtharajah, R.S. Wajah Yesus di Asia. Jakarta: BPK Gunung Mulia, 2007.

Wijanarko, Robertus, "Poskoloialisme dan studi teologi: sebuah pengantar." Jurnal, Studia, philosophica et theological, Vol. 8 No. 2 Oktober 2008, STFT Widya Sasana Malang

Young, Robert J.C. Postcolonialism: A Very Short Introduction. New York: Oxford University Press, 2003. 